\title{
Occurrence and Abundance of Dermacentor reticulatus in the Habitats of the Ecological Corridor of the Wieprz River, Eastern Poland
}

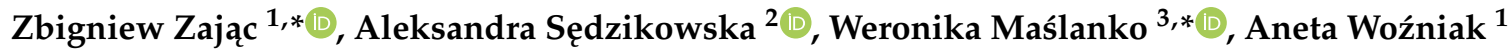 \\ and Joanna Kulisz ${ }^{1}$ (D)
}

1 Chair and Department of Biology and Parasitology, Medical University of Lublin, Radziwiłłowska 11 st., 20-080 Lublin, Poland; aneta.wozniak@umlub.pl (A.W.); joanna.kulisz@umlub.pl (J.K.)

2 Department of General Biology and Parasitology, Medical University of Warsaw, Chałubińskiego 5 st., 02-004 Warsaw, Poland; aleksandra.sedzikowska@wum.edu.pl

3 Department of Animal Ethology and Wildlife Management, University of Life Sciences in Lublin, Akademicka 13 St., 20-950 Lublin, Poland

* Correspondence: zbigniew.zajac@umlub.pl (Z.Z.); weronika.maslanko@up.lublin.pl (W.M.)

check for updates

Citation: Zając, Z.; Sędzikowska, A.; Maślanko, W.; Woźniak, A.; Kulisz, J. Occurrence and Abundance of Dermacentor reticulatus in the Habitats of the Ecological Corridor of the Wieprz River, Eastern Poland. Insects 2021, 12, 96. https://doi.org/ 10.3390 /insects12020096

Academic Editor: Gottlieb Yuval Received: 13 December 2020

Accepted: 22 January 2021

Published: 23 January 2021

Publisher's Note: MDPI stays neutral with regard to jurisdictional claims in published maps and institutional affiliations.

Copyright: (c) 2021 by the authors. Licensee MDPI, Basel, Switzerland. This article is an open access article distributed under the terms and conditions of the Creative Commons Attribution (CC BY) license (https:// creativecommons.org/licenses/by/ $4.0 /)$.
Simple Summary: Ecological corridors are zones of natural vegetation, which connect with other vegetation strips to create migration routes and provide shelter for animals. One of the longest ecological corridors in eastern Poland runs along the Wieprz River valley. We examined the occurrence and relative abundance of Dermacentor reticulatus in research plots established in the river valley and confirmed the presence of this tick species in each of the seven examined sites. The results of our research show that the habitats of the river ecological corridor can be regarded as preferred habitats of $D$. reticulatus in eastern Poland.

Abstract: Ecological corridors are zones of natural vegetation, which connect with other vegetation strips to create migration routes for animals and plants. The aim of our study was to investigate the occurrence and relative abundance of Dermacentor reticulatus in various habitats of the ecological corridor of the Wieprz River in eastern Poland. Ticks were collected using the flagging method in seven sites within the ecological corridor of the Wieprz River, i.e., one of the longest uninterrupted vegetation strips in eastern Poland. The presence of $D$. reticulatus adults was confirmed in each of the examined sites. The autumn peak of tick activity dominated in most plots. During this period, on average up to 309.7 individuals were collected within $30-\mathrm{min}$. The results of our study show that, due to the high abundance of local D. reticulatus populations, the habitats located in the ecological corridor of the Wieprz River can be regarded as preferred habitats of this tick species.

Keywords: ecological corridors; ticks; tick activity; tick occurrence; Dermacentor reticulatus

\section{Introduction}

Ecological corridors are zones of natural vegetation located mainly along river valleys, mountain ranges, and forest complexes. They serve as migration routes for animals, plants, and fungi. By connecting with other vegetation belts, they create an uninterrupted network providing shelter for animals and enabling them to acquire food and raise their offspring [1]. They are extremely important, given the progressive fragmentation of the environment caused by human activity [2]. Although the vast majority of ecological corridors stretch along large areas that have not been changed by human activity or have been only slightly transformed, some smaller-scale ecological corridors can be identified within large conurbations [3].

The concept of ecological corridors is currently being implemented in many European countries in accordance with European legislation [4]. Ecological corridors with national, regional, and even continental importance are being established [4,5]. Several ecological 
corridor projects have been implemented in Poland. The first one, created in the 1990s (the National Ecological Network (ECONET-PL project), was a coherent part of the European Ecological Network (EECONET). Particular emphasis in this project was placed on ecological corridors stretching along watercourses. In the 2000s, it was modified by the fusion of ECONET-PL with the National System of Protected Areas, with particular emphasis on coherence with Natura 2000 areas [6].

In eastern Poland, three large ecological corridors have been established along river valleys, i.e., along the Vistula and Bug rivers, which are classified as routes with European importance and smaller corridor with regional importance along the Wieprz River (Figure 1).

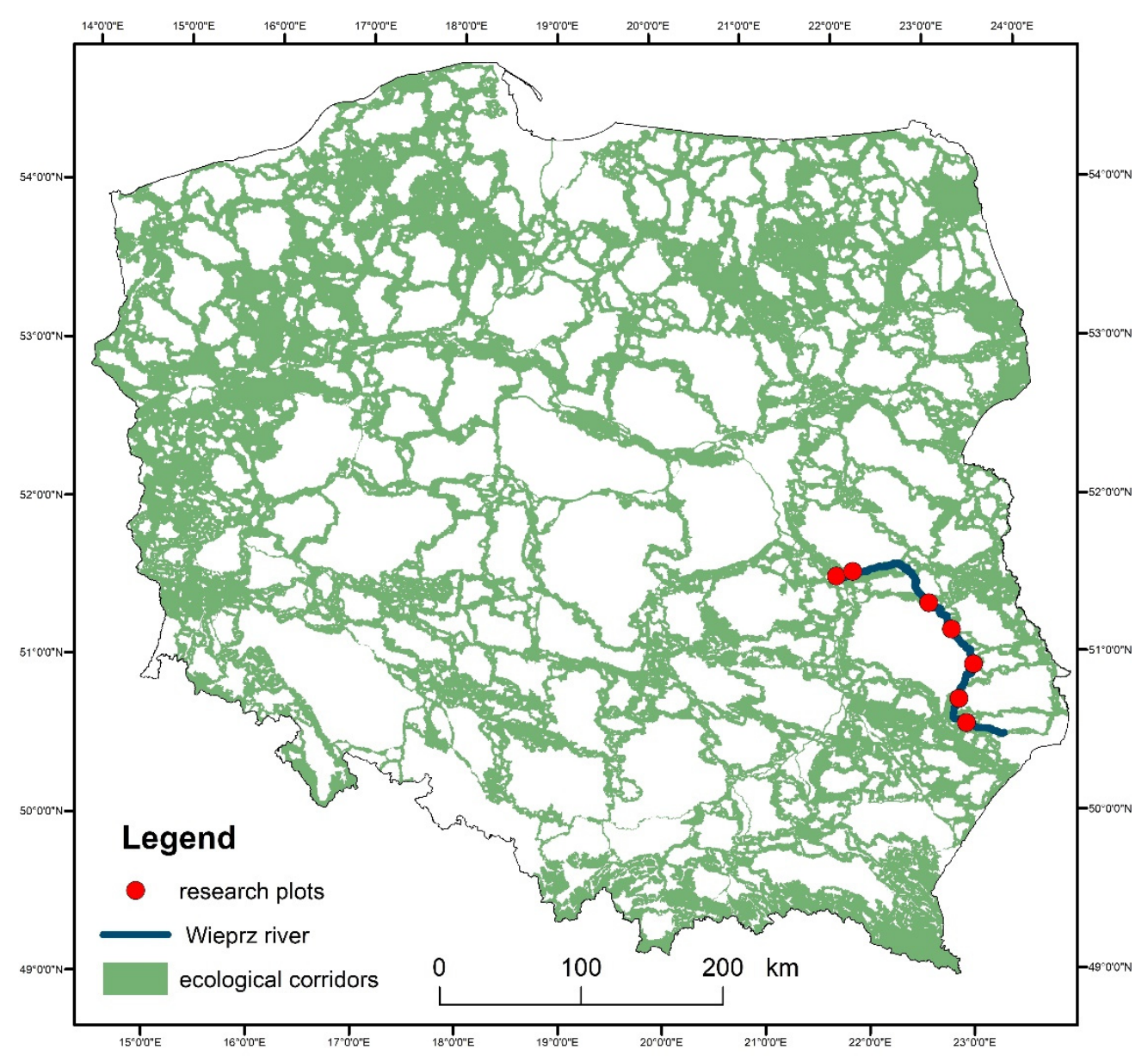

Figure 1. Network of ecological corridors in Poland based on the study by the Mammal Research Institute of the Polish Academy of Sciences [7]. The ecological river corridors in Poland are marked in green; the blue line marks the course of the ecological corridor in the Wieprz River valley.

Investigations conducted so far on the occurrence of ticks in river valleys in various parts of the world have confirmed that this type of habitat offers these arthropods favorable living conditions. Ixodes scapularis, I. dammini, I. ricinus, Dermacentor andersoni, and D. variabilis are some of the species that have been collected in these habitats [8-11]. Researchers have reported the presence of $D$. reticulatus in river valleys of Poland as well [12]; however, to the best of our knowledge, no simultaneous comparative studies have been carried out to date on the occurrence and abundance of this species in habitats of river valleys.

Additionally, comprehensive knowledge of the ecology and biology of D. reticulatus ticks is important due to their great epidemiological and veterinary importance, i.e., the role of this species as vectors of numerous pathogens [13]. The ticks transmit TBE virus, Omsk hemorrhagic fever virus, protozoa Babesia canis, B. caballi, and Theileria equi, 
bacteria Anaplasma marginale, and rickettsiae Rickettsia raoultii, R. slovaca [14-17]. Moreover, R. helvetica, Borrelia burgdorferi s.l., Coxiella burneii, Francisella tularensis (with an unknown vector role) have been detected in D. reticulatus ticks [14].

The aim of our study was to investigate the occurrence and relative abundance of D. reticulatus ticks in habitats located in the immediate vicinity of a river bed (the ecological corridor of the Wieprz River). The relevance of this study is supported by the increasing number of reports on the presence of D. reticulatus in areas where the species was not found previously, e.g., north, western, south-western, and central Poland [18-20]. Whereas, eastern Poland is an area of high density of D. reticulatus [21] however, there are no previous simultaneous studies on monitoring of seasonal activity of that species in various physicogeographical areas including influence of abiotic and biotic factors in the area of river ecological corridor.

\section{Materials and Methods}

\subsection{Study Area}

The study was carried out in the ecological corridor along the Wieprz River (Figure 1), i.e., the longest river in Lublin Province (eastern Poland) with a length of $303 \mathrm{~km}$ and a basin area of $10,400 \mathrm{~km}^{2}$ [22]. As a hydrographic axis of the region, the river valley constitutes an ecological corridor with favorable living conditions for fauna and flora and a route of undisturbed migration for animals [7,23].

As shown by the physico-geographical division of Poland proposed by Kondracki [24], the Wieprz River flows through seven mesoregions differing in their geomorphological structure, water conditions, thermal conditions, and vegetation cover (Table 1). Within each of these mesoregions, one research plot (marked as A-G) (Figure 2, Table 1) was established near the river to collect ticks (see Section 2.2).

Table 1. General characteristics of the mesoregions and the tick collection sites.

\begin{tabular}{|c|c|c|}
\hline Plot/Geographical Coordinates & Mesoregion/Research Plot & $\begin{array}{l}\text { Characteristics of the } \\
\text { Mesoregion/Research Plots }\end{array}$ \\
\hline \multirow[b]{2}{*}{$\begin{array}{c}\mathrm{A} \\
51.540^{\circ} \mathrm{N}, 21.837^{\circ} \mathrm{E}\end{array}$} & Middle Vistula Valley & \multirow[b]{2}{*}{$\begin{array}{l}\text { Area adjacent to the Vistula River, } 1-1.5 \\
\text { km wide. Chalk substrate. Shrub } \\
\text { vegetation in the immediate vicinity of } \\
\text { the river. The research plot was } \\
\text { established in a clearing surrounded by } \\
\text { shrub vegetation with solitary } \\
\text { deciduous trees. }\end{array}$} \\
\hline & & \\
\hline \multirow[b]{2}{*}{$\begin{array}{c}\mathrm{B} \\
51.608^{\circ} \mathrm{N}, 22.384^{\circ} \mathrm{E}\end{array}$} & Wieprz Glacier Valley & \multirow[b]{2}{*}{$\begin{array}{l}\text { Lower course of the Wieprz River with } \\
\text { many meanders. Water sediment } \\
\text { substrate. Wetland area. The research } \\
\text { plot was established in an unused } \\
\text { agricultural meadow adjacent to a mixed } \\
\text { forest near the Wieprz River. }\end{array}$} \\
\hline & & \\
\hline$\frac{\mathrm{C}}{51.356^{\circ} \mathrm{N}, 22.761^{\circ} \mathrm{E}}$ & Świdnik Plateau & $\begin{array}{l}\text { Area located at the confluence of the } \\
\text { Wieprz and Bystrzyca Rivers. Flat } \\
\text { denudation plain devoid of loess cover. } \\
\text { Agricultural region with a low } \\
\text { proportion of forests. The research plot } \\
\text { was established near the Wieprz River, in } \\
\text { an unused meadow surrounded by } \\
\text { arable fields and fallow land at a distance } \\
\text { of approx. } 2 \mathrm{~km} \text { from a mixed forest. }\end{array}$ \\
\hline
\end{tabular}


Table 1. Cont.

\begin{tabular}{|c|c|c|}
\hline Plot/Geographical Coordinates & Mesoregion/Research Plot & $\begin{array}{c}\text { Characteristics of the } \\
\text { Mesoregion/Research Plots }\end{array}$ \\
\hline \multicolumn{3}{|c|}{ Dorohusk Basin } \\
\hline $\begin{array}{c}\mathrm{D} \\
51.180^{\circ} \mathrm{N}, 22.979^{\circ} \mathrm{E}\end{array}$ & & $\begin{array}{l}\text { Upland region with Cretaceous rocks in } \\
\text { the substrate. Numerous peat bogs and } \\
\text { ground depressions are a characteristic } \\
\text { feature. The research plot was established } \\
\text { in meadow with clearly progressive } \\
\text { ecological succession. }\end{array}$ \\
\hline $\begin{array}{c}\mathrm{E} \\
50.951^{\circ} \mathrm{N}, 23.170^{\circ} \mathrm{E}\end{array}$ & Grabowiec Upland & $\begin{array}{l}\text { Loess-covered hump formed of Upper } \\
\text { Cretaceous rocks. Numerous } \\
\text { watercourses joining the Wieprz River. } \\
\text { The mesoregion is located on the border } \\
\text { of mixed forests and a forest-steppe zone } \\
\text { The maximum altitude is } 313 \mathrm{~m} \text { a.s.l. The } \\
\text { research plot was established in an } \\
\text { agriculturally unused meadow } \\
\text { surrounded by a permanent 5-ha wetland } \\
\text { land on one side and a hill escarpment on } \\
\text { the other side (approx. } 15 \mathrm{~m} \\
\text { relative height). }\end{array}$ \\
\hline $\begin{array}{c}\mathrm{F} \\
50.739^{\circ} \mathrm{N}, 23.015^{\circ} \mathrm{E}\end{array}$ & Zamość Basin & $\begin{array}{l}\text { Extensive denudation with chalk marls in } \\
\text { the substrate. This plain wetland area is } \\
\text { situated approx. 80-m lower (relative } \\
\text { height) than the surrounding highlands. } \\
\text { The research plot was established in the } \\
\text { Wieprz River valley, in an area covered by } \\
\text { meadow vegetation. }\end{array}$ \\
\hline $50.584^{\circ} \mathrm{N}, 23.077^{\circ} \mathrm{E}$ & Middle Roztocze & $\begin{array}{l}\text { Irregular hills on calcareous substrate } \\
\text { without loess cover. Heavily forested } \\
\text { area. Annual precipitation sum above the } \\
\text { average for the Province. The research } \\
\text { plot was established along the bank of the } \\
\text { Wieprz River in an area covered by } \\
\text { meadow vegetation with shrub islets. }\end{array}$ \\
\hline
\end{tabular}

Additionally, the vegetation cover in the plots and their surroundings was analyzed. Based on the list of plant species compiled during the field study, the plant communities were classified into associations (in the case of scrubs and shrubs) or classes (meadow vegetation) as in Matuszkiewicz [25]. In the next step, using an orthophotomap downloaded from the WMS Geoportal website [26], the forms of vegetation cover visible in the satellite photos were compared with the plant communities identified previously (Figure A1). Next, using the ArcGIS software (Esri, Redlands, CA, USA) and based on the photointerpretation methods $[27,28]$, the area and percentage share of specific plant communities within a radius of $50 \mathrm{~m}$ from the center of the research field were calculated (the diameter of the circle determined in this way corresponded to the length of the transect from which ticks were collected). Additionally, while determining the radius of the studied area, the locomotor abilities of $D$. reticulatus were taken into account [29]. 


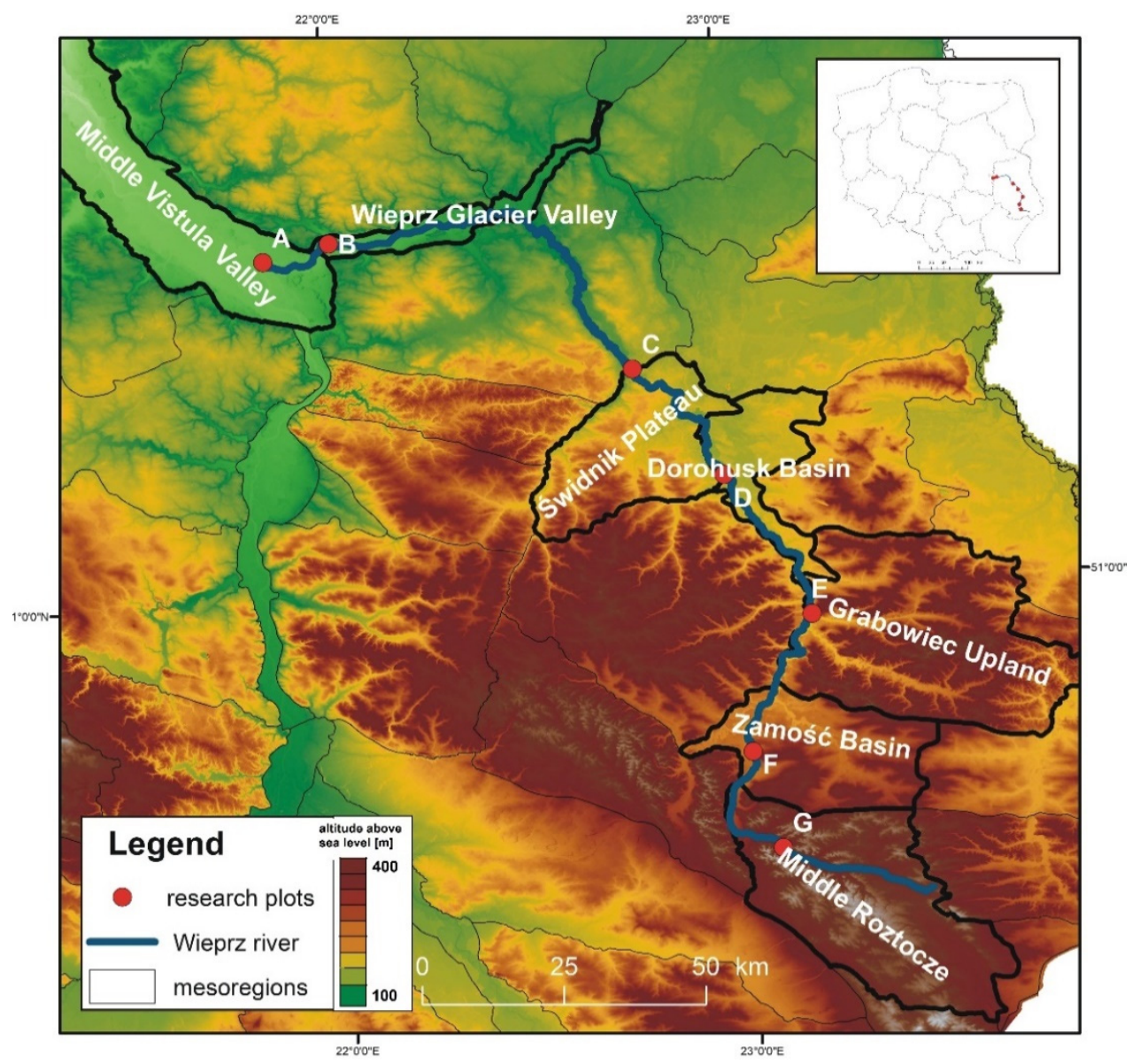

Figure 2. Location of the research plots $(A-G)$. The Wieprz River is indicated by the blue line. Based on geoportal.gov.pl [26].

\subsection{Tick Surveillance}

The field studies were carried out between autumn 2018 and autumn 2019. Ticks were collected at regular two-week intervals from the end of February to June (spring period) and from September to mid-November (autumn period) (with modification in the event of unfavorable weather conditions), except the summer months when $D$. reticulatus adults remain inactive in eastern Poland. Ticks were collected during their diurnal peaks of activity, i.e., between 11:00 and 14:00 [30]. The flagging method, which is commonly used for this type of research, was used in accordance with the procedure described by Nowak-Chmura [31]. It consisted in sweeping the vegetation with a white flannel cloth tied to a pole. After covering a distance of approx. $2 \mathrm{~m}$, the flag was turned over, and ticks attached to the cloth were collected using tweezers and placed in a sterile $100-\mathrm{cm}^{3}$ plastic container labeled with information about the plot and date of collection. Each time, ticks were collected in each plot for $30 \mathrm{~min}$.

Additionally, the Data Logger R6030 (Reed Instruments, Wilmington, NC, USA) was used during each tick collection round to measure the weather conditions, air temperature, and relative humidity. The readings were taken at a height of approx. $50 \mathrm{~cm}$, i.e., the average height at which ticks were collected.

In the laboratory, the species, sex, and developmental stage of the ticks were determined using a Zeiss STEMI DV4 stereoscopic microscope (Carl Zeiss Light Microscopy, Göttingen, Germany) and a tick identification key [31]. Next, the ticks were placed in an ULTF freezer (Arctico, Esbjerg, Denmark) at $-80^{\circ} \mathrm{C}$. 


\subsection{Statistical Analysis}

The statistical tests were chosen based on the characteristics of the distribution of the analyzed variables with the use of the Lilliefors test.

The significance of differences in the number of D. reticulatus females and males collected in the research plots was checked with the Wilcoxon test. The differences between the number of ticks that were active in spring and autumn in each study plot were analyzed with the Kruskal-Wallis test. Using one-way ANOVA for independent variables, the differences in the number of active ticks between all research sites were analyzed and the significance of differences in weather conditions between the plots was examined. ANOVA was also used to test the significance of differences in the land cover structure between the study sites. The effect of air temperature and relative humidity on $D$. reticulatus activity was verified with the Sperman rho-correlation test.

A level of significance of $p \leq 0.05$ was assumed in all statistical tests. The statistical analysis was conducted using Statistica 10PL (StatSoft, TIBCO Software Inc., Palo Alto, CA, USA) software.

\section{Results}

\subsection{Occurrence and Relative Abundance of Local Dermacentor reticulatus Populations}

Only $D$. reticulatus adults were collected throughout the study period. In total, 17,389 ticks were collected from all plots, with 9440 females and 7949 males (Figures 3-9, Table 2). Higher numbers of active females than males were observed in each plot. This difference was statistically significant in the entire study period $(Z=-7.353, p<0.001)$. Additionally, 98 females, 130 males, and 55 nymphs of I. ricinus were collected simultaneously with $D$. reticulatus from all study plots throughout the study period.

PLOT A

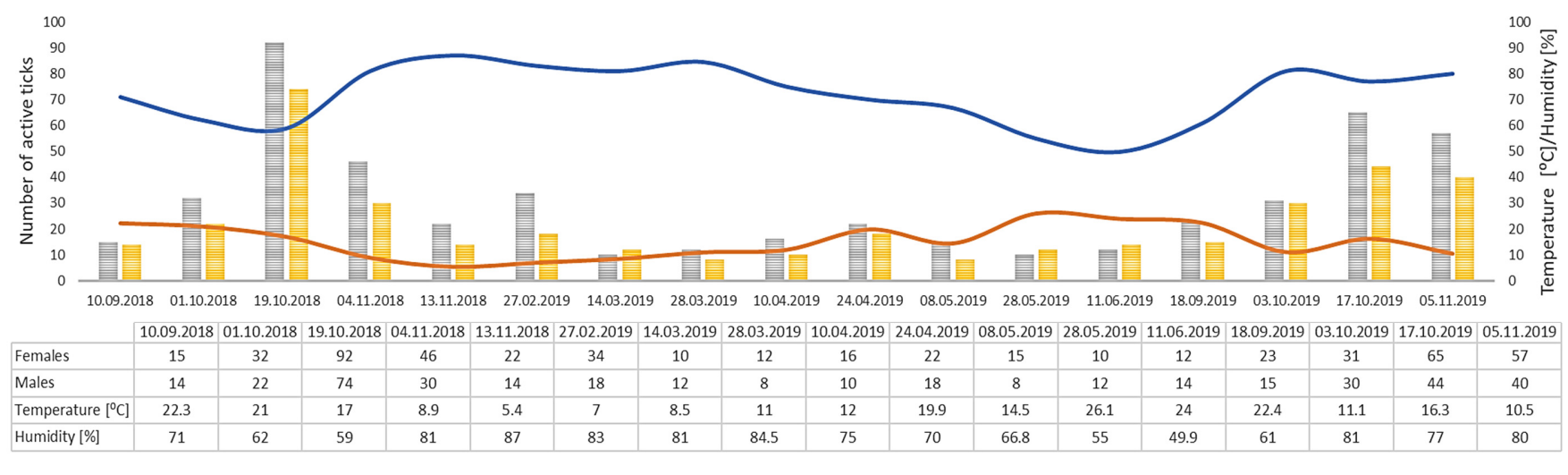

”Females $\Longrightarrow$ Males —Temperature $\left.{ }^{\circ} \mathrm{C}\right]$ - Humidity $[\%]$

Figure 3. Abundance and seasonal activity of Dermacentor reticulatus adults in research plot A and weather conditions prevailing during tick collection. Predominance of active ticks in autumn. 


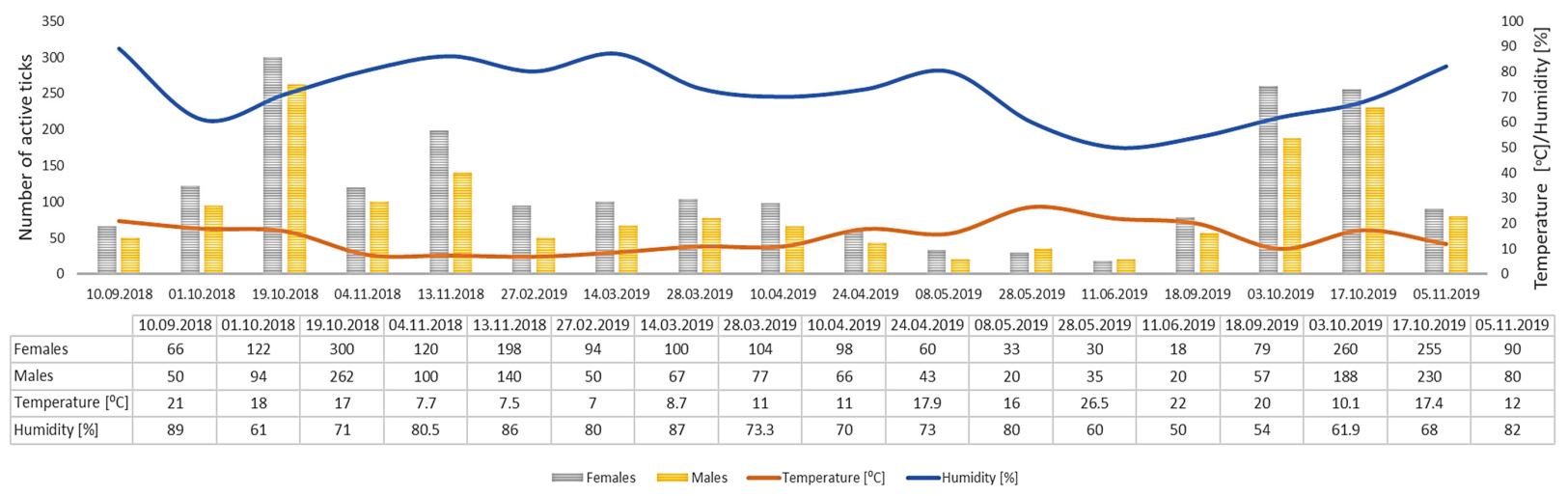

Figure 4. Abundance and seasonal activity of Dermacentor reticulatus adults in research plot B and weather conditions prevailing during tick collection. Predominance of active ticks in autumn.

PLOT C

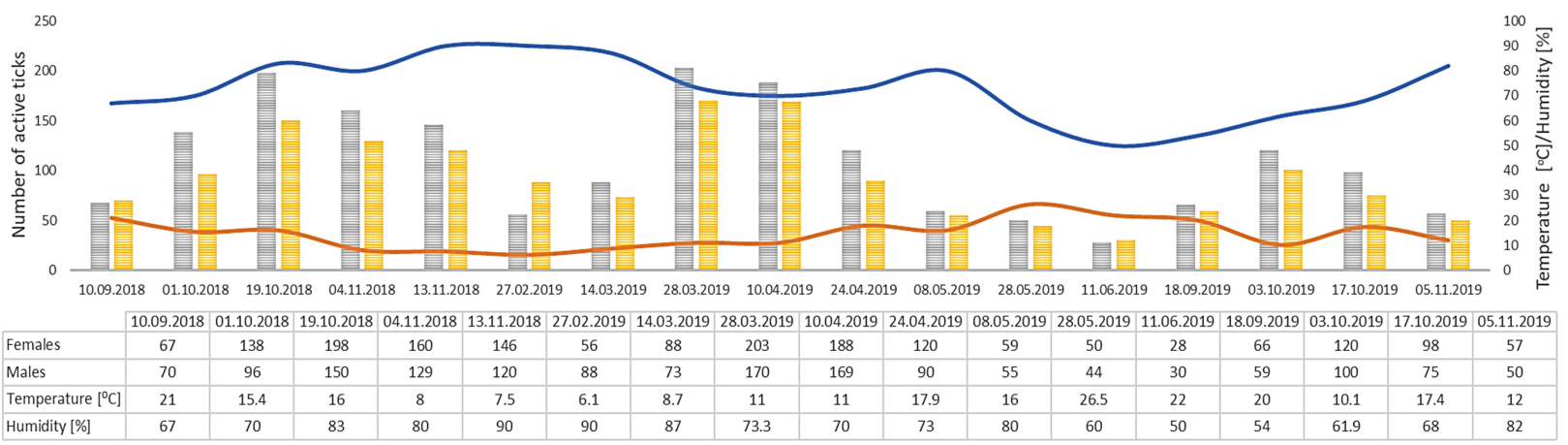

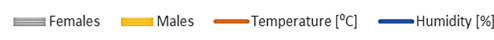

Figure 5. Abundance and seasonal activity of Dermacentor reticulatus adults in research plot $\mathrm{C}$ and weather conditions prevailing during tick collection. Predominance of active ticks in spring.

PLOT D

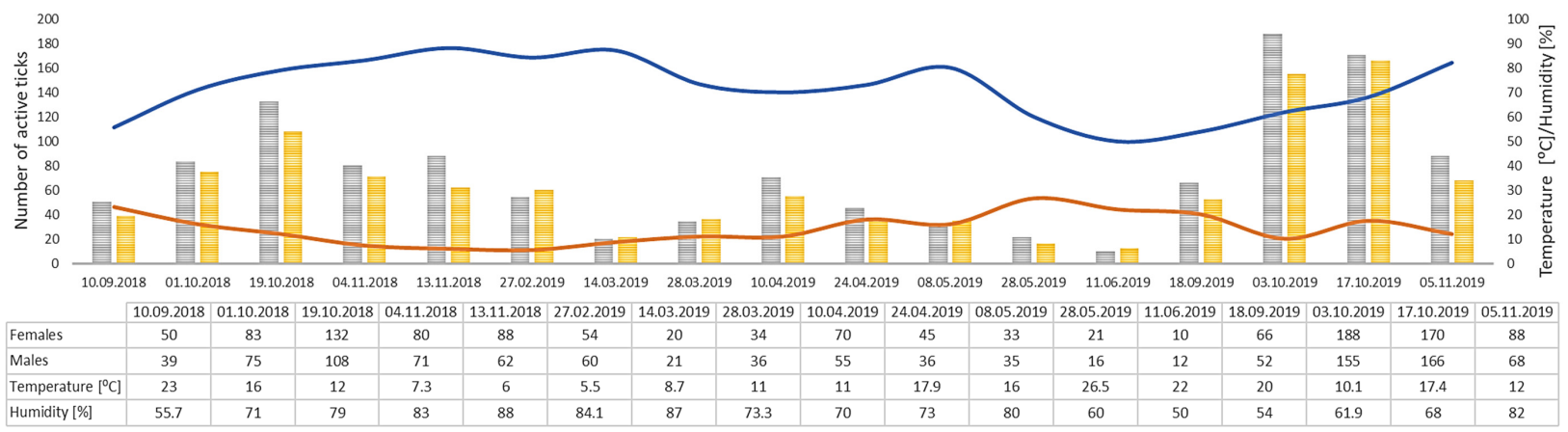

—Females $\Longrightarrow$ Males —Temperature $\left[{ }^{\circ} \mathrm{C}\right]$ —Humidity $[\%]$

Figure 6. Abundance and seasonal activity of Dermacentor reticulatus adults in research plot D and weather conditions prevailing during tick collection. Predominance of active ticks in autumn. 


\section{PLOT E}

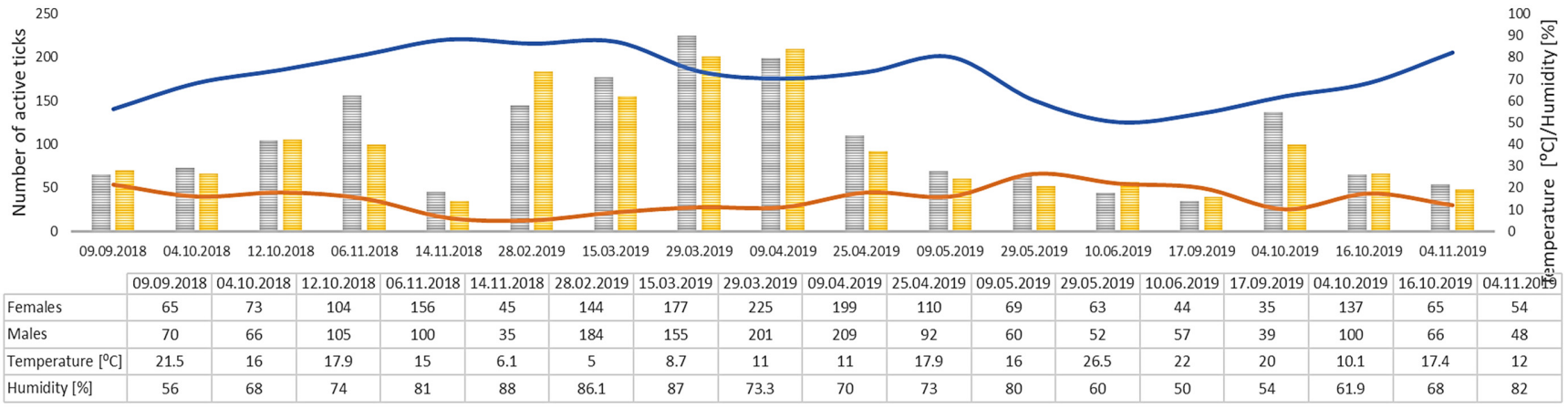

”Females $=$ Males Temperature $\left[{ }^{\circ} \mathrm{C}\right]$ - Humidity [\%]

Figure 7. Abundance and seasonal activity of Dermacentor reticulatus adults in research plot E and weather conditions prevailing during tick collection. Predominance of active ticks in spring.

\section{PLOT F}

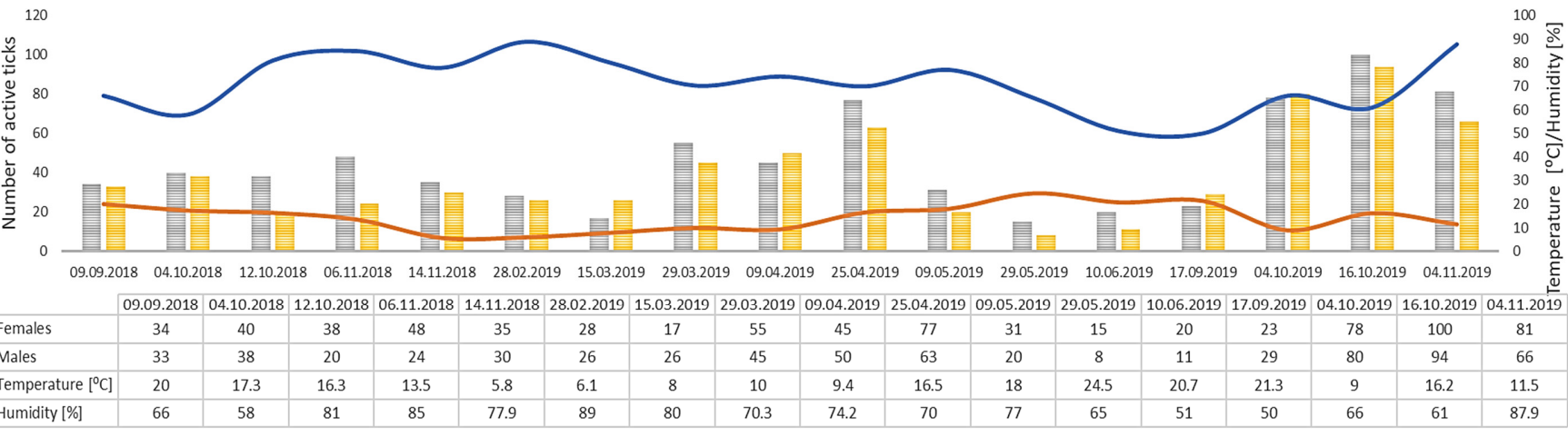

EFemales

Figure 8. Abundance and seasonal activity of Dermacentor reticulatus adults in research plot $\mathrm{F}$ and weather conditions prevailing during tick collection. Predominance of active ticks in autumn.

PLOT G

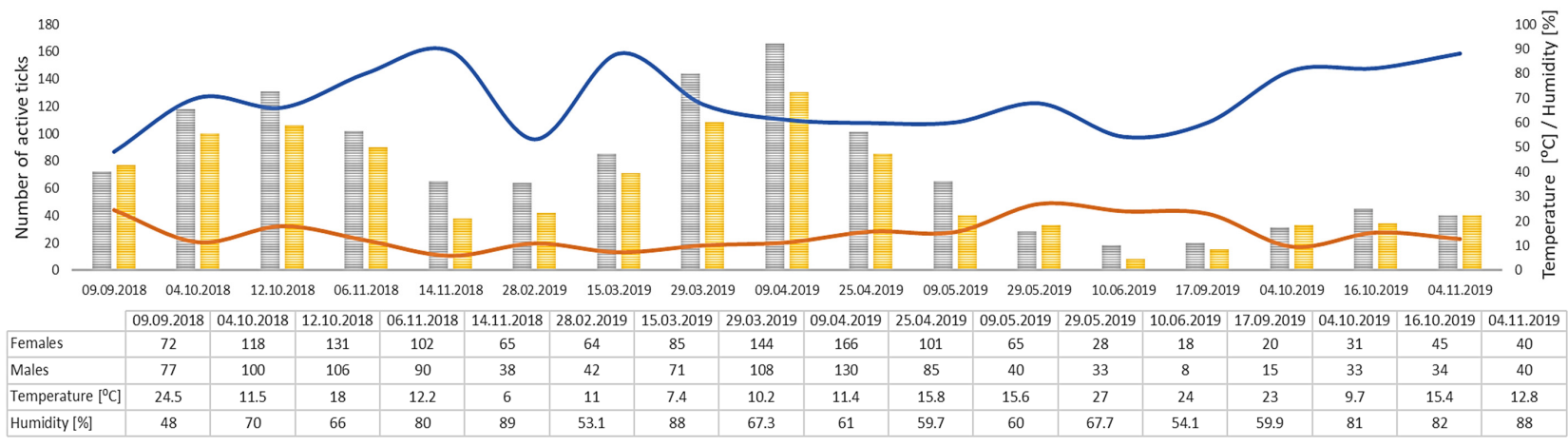

—Females $\Longrightarrow$ Males —Temperature $\left[{ }^{\circ} \mathrm{C}\right]$ —Humidity [\%]

Figure 9. Abundance and seasonal activity of Dermacentor reticulatus adults in research plot $\mathrm{G}$ and weather conditions prevailing during tick collection. Predominance of active ticks in autumn. 


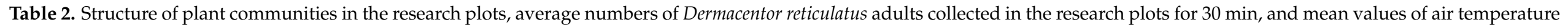
and humidity prevailing at the time of tick collection.

\begin{tabular}{|c|c|c|c|c|c|c|c|}
\hline \multirow{2}{*}{ Plot } & \multirow{2}{*}{ Structure of Plant Communities in Research Plots [\%] } & \multirow{2}{*}{ Season * } & \multicolumn{5}{|c|}{ Mean Value \pm SD } \\
\hline & & & $\mathrm{T}\left[{ }^{\circ} \mathrm{C}\right]$ & $\mathbf{H}[\%]$ & $\mathbf{F}$ & $\mathbf{M}$ & $\mathbf{F}+\mathbf{M}$ \\
\hline \multirow{3}{*}{$\mathrm{A}$} & \multirow{3}{*}{$\begin{array}{l}\text { Cl. Molinio-Arrhenatheretea (79.8) } \\
\text { Ass. Tilio cordatae-Carpinetum betuli (20.2) }\end{array}$} & Autumn 2018 & 14.9 & 72.0 & $41.4 \pm 27.3$ & $30.8 \pm 22.4$ & $72.2 \pm 49.6$ \\
\hline & & Spring 2019 & 15.4 & 70.6 & $16.3 \pm 7.6$ & $12.5 \pm 3.7$ & $28.8 \pm 11.1$ \\
\hline & & Autumn 2019 & 15.0 & 74.7 & $44.0 \pm 17.4$ & $32.2 \pm 11.8$ & $76.2 \pm 29.2$ \\
\hline \multirow[b]{2}{*}{ B } & \multirow{2}{*}{$\begin{array}{l}\text { Cl. Molinio-Arrhenatheretea (86.2) } \\
\text { Ass. Salicetum albo-Fragilis (13.8) }\end{array}$} & Autumn 2018 & 14.2 & 77.5 & $161.2 \pm 81.1$ & $129.2 \pm 72.2$ & $290.4 \pm 153.3$ \\
\hline & & Spring 2019 & 15.0 & 71.6 & $67.1 \pm 33.7$ & $47.2 \pm 20.2$ & $114.3 \pm 53.9$ \\
\hline \multirow{3}{*}{$\mathrm{C}$} & \multirow{3}{*}{$\begin{array}{l}\text { Cl. Molinio-Arrhenatheretea (70.1) } \\
\text { Arable land (29.9) }\end{array}$} & Autumn 2018 & 13.5 & 78.0 & $141.8 \pm 42.7$ & $113.0 \pm 27.6$ & $254.8 \pm 70.3$ \\
\hline & & Spring 2019 & 14.9 & 72.9 & $99.0 \pm 61.4$ & $89.8 \pm 49.8$ & $188.8 \pm 111.2$ \\
\hline & & Autumn 2019 & 14.8 & 66.4 & $85.2 \pm 25.1$ & $71.0 \pm 18.9$ & $156.2 \pm 44.0$ \\
\hline \multirow{3}{*}{$\mathrm{D}$} & \multirow{3}{*}{$\begin{array}{l}\text { Molinio-Arrhenatheretea (89.3) } \\
\text { All. Salicion albae (10.7) }\end{array}$} & Autumn 2018 & 12.8 & 75.3 & $86.6 \pm 26.3$ & $71.0 \pm 22.3$ & $157.6 \pm 48.6$ \\
\hline & & Spring 2019 & 14.8 & 72.1 & $35.8 \pm 16.7$ & $33.8 \pm 14.9$ & $69.6 \pm 31.6$ \\
\hline & & Autumn 2019 & 14.9 & 66.4 & $128.0 \pm 51.9$ & $110.2 \pm 50.7$ & $238.2 \pm 102.6$ \\
\hline \multirow[t]{2}{*}{$\mathrm{E}$} & \multirow{2}{*}{$\begin{array}{l}\text { Cl. Molinio-Arrhenatheretea (57.5) } \\
\text { Arable land (22.4) } \\
\text { Trees (3.0) } \\
\text { Other meadow communities (17.1) }\end{array}$} & Spring 2019 & 14.7 & 72.4 & $128.8 \pm 63.4$ & $126.2 \pm 63.7$ & $255.0 \pm 127.1$ \\
\hline & & Autumn 2019 & 14.8 & 66.5 & $72.7 \pm 38.6$ & $63.3 \pm 23.3$ & $136.0 \pm 61.9$ \\
\hline \multirow{3}{*}{$\mathrm{F}$} & \multirow{3}{*}{$\begin{array}{l}\text { Cl. Molinio-Arrhenatheretea (97.3) } \\
\text { All. Salicion albae (2.7) }\end{array}$} & Autumn 2018 & 14.5 & 73.5 & $39.0 \pm 4.9$ & $29.0 \pm 6.3$ & $68.0 \pm 11.0$ \\
\hline & & Spring 2019 & 14.1 & 72.0 & $36.0 \pm 20.2$ & $31.2 \pm 18.3$ & $67.2 \pm 38.5$ \\
\hline & & Autumn 2019 & 14.5 & 66.2 & $70.5 \pm 28.6$ & $67.2 \pm 24.2$ & $137.7 \pm 46.9$ \\
\hline \multirow{3}{*}{ G } & \multirow{3}{*}{$\begin{array}{l}\text { Cl. Molinio-Arrhenatheretea (66.3) } \\
\text { Arable lands (8.0) } \\
\text { Other meadow communities (6.2) } \\
\text { Cl. Querco-Fagetea (12.5) } \\
\text { Other (7.0) }\end{array}$} & Autumn 2018 & 14.4 & 70.6 & $97.6 \pm 25.5$ & $82.2 \pm 24.1$ & $179.8 \pm 49.6$ \\
\hline & & Spring 2019 & 15.3 & 63.8 & $83.8 \pm 48.5$ & $64.6 \pm 38.6$ & $148.4 \pm 87.1$ \\
\hline & & Autumn 2019 & 15.2 & 77.7 & $34.0 \pm 10.6$ & $30.5 \pm 9.5$ & $64.5 \pm 20.1$ \\
\hline
\end{tabular}

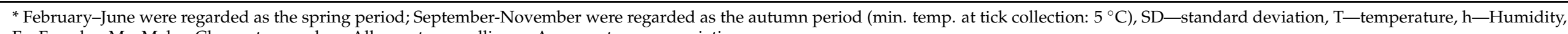
F-Females, M-Males, $\mathrm{Cl} —$ syntaxon: class; All—syntaxon: alliance, Ass—syntaxon: association. 
The greatest numbers of $D$. reticulatus were collected in plots located in the middle course of the river, i.e., B (on average from 114.3 specimens in spring to 309.7 specimens in autumn per collection), C (on average from 188.8 ticks in spring to 254.8 ticks in autumn per collection), and $\mathrm{E}$ (on average from 136.0 specimens in autumn to 255.0 specimens in spring per collection). The lowest numbers of ticks were collected in the research plot located at the confluence of the Wieprz River with the Vistula River (plot A; on average from 28.8 specimens in spring to 76.2 specimens in autumn per collection) (Table 2). Overall, the research plots differed significantly in the number of active ticks $(\mathrm{F}=6.928, p<0.01)$.

Clear differences in the number of active adult $D$. reticulatus specimens were noted between spring and autumn at each research plot (Figures 3-9, Table 2). In plots A, B, D, and $F$, a higher activity peak was observed in autumn than in spring. The percentage of specimens that were active in autumn in plot $\mathrm{D}$ reached $71.0 \%$ (Figure 6, Table 2). In plots $\mathrm{C}$ and $\mathrm{E}$, greater numbers of ticks were collected in spring (Figures 5 and 7, Table 2).

A statistically significant difference in the number of active ticks between the spring and autumn collection was found in plots $\mathrm{A}(\mathrm{H}=8.333, p=0.004), \mathrm{B}(\mathrm{H}=6.750, p=0.009)$, $\mathrm{D}(\mathrm{H}=10.083, p=0.001)$.

In each of the research sites, the dominant community was represented by the meadow vegetation from the Molinio-Arrhenatheretea class (from 57.5\% to $97.3 \%$ of the area). The greatest numbers of $D$. reticulatus, i.e., on average up to 309.7 individuals, were collected from sites with patches of riparian vegetation (Salicetum albo-Fragilis) accompanying the dominant meadow vegetation (Table 2). The structure of the cover of the research plots with the plant communities did not differ significantly $(\mathrm{F}=0.00, p=1.000)$.

\subsection{Impact of Weather Conditions on Tick Activity}

The ticks were collected in a temperature range of $5.0-27.0^{\circ} \mathrm{C}$ and relative humidity of 48.0-90.0\%. During tick collection, the weather conditions did not differ significantly between the plots (temperature: $\mathrm{F}=0.057, p=0.999$; relative humidity: $\mathrm{F}=0.168, p=0.984$ )

In each of the research plots, the number of active ticks declined with an increase in air temperature (Figure 10). No such correlation was observed in the case of relative air humidity, except for plot E, where increased humidity was accompanied by higher activity of $D$. reticulatus specimens (Figure 11) A statistically significant negative correlation was found between the number of active $D$. reticulatus adults and air temperature $\left(\mathrm{r}_{\mathrm{S}}=-0.304\right.$, $p<0.001)$, and there was a statistically non-significant positive correlation between the air relative humidity and the number of active ticks $\left(r_{\mathrm{s}}=0.122, p=0.183\right)$. 
Plot A

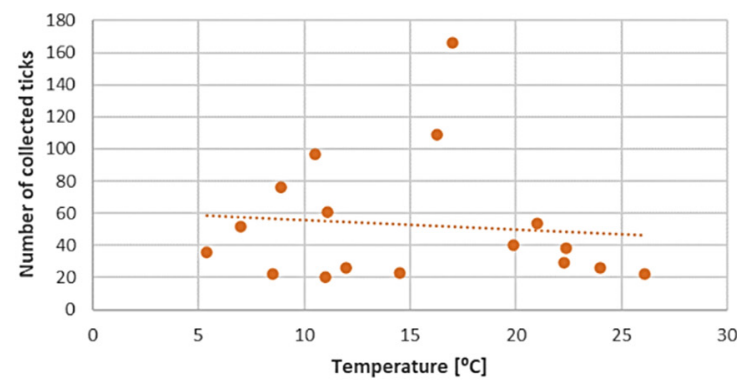

Plot C
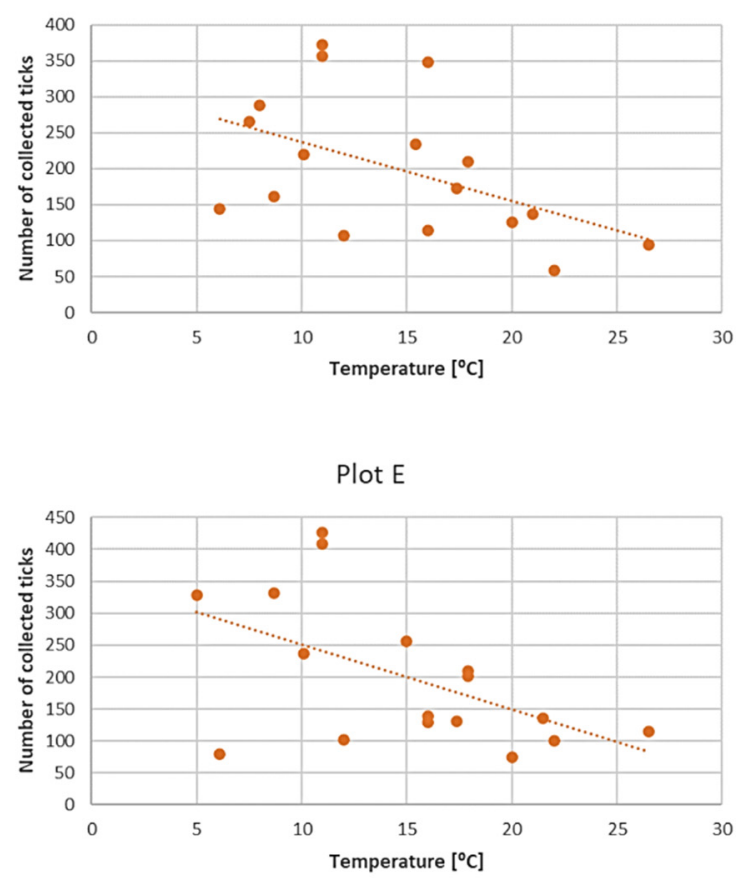

Plot B

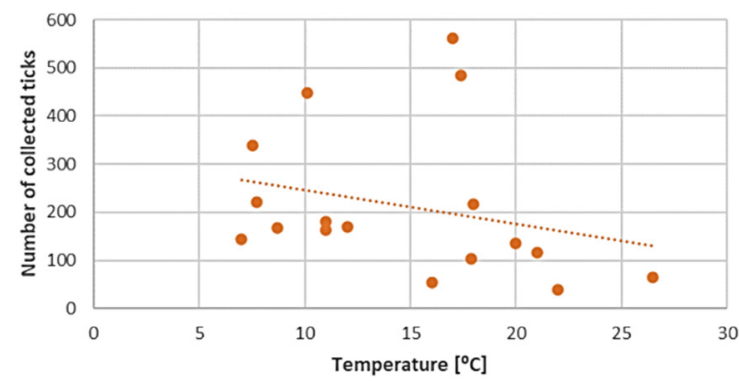

Plot D

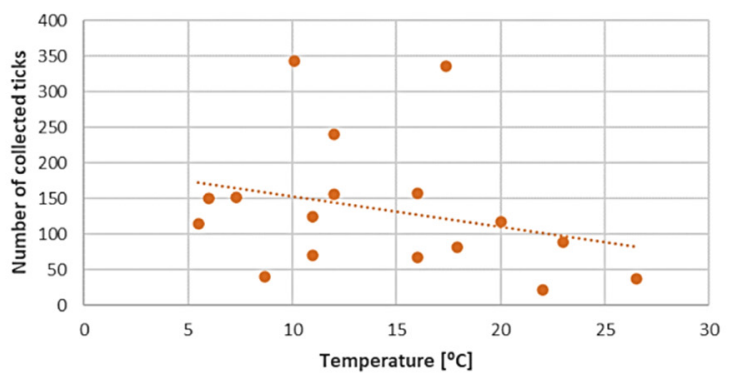

Plot F

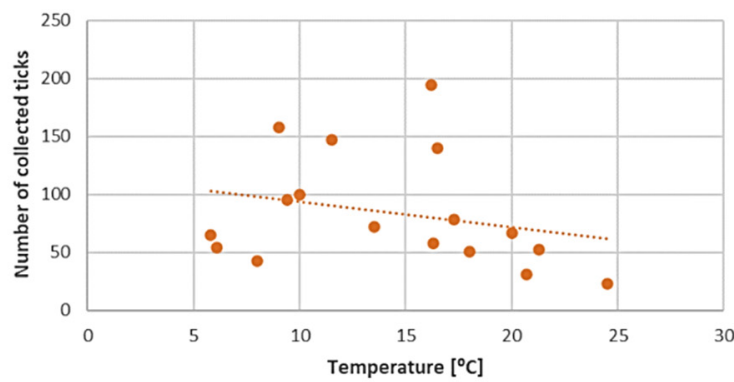

Plot G

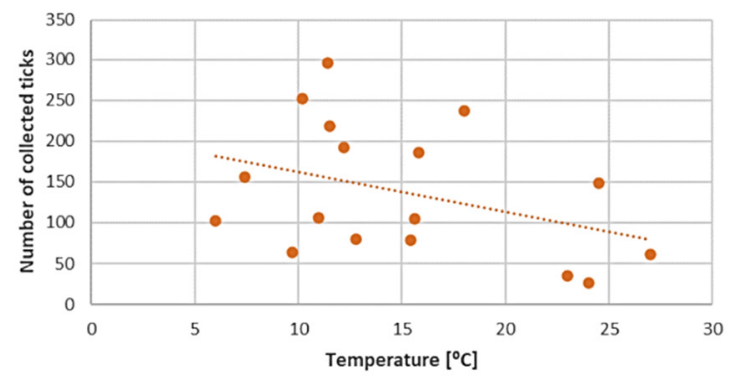

Figure 10. Relationship between air temperature and the number of active Dermacentor reticulatus adults in the research plots. 
Plot A

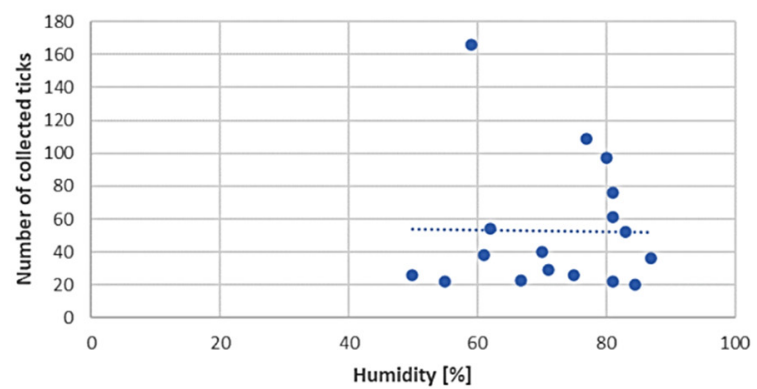

Plot C

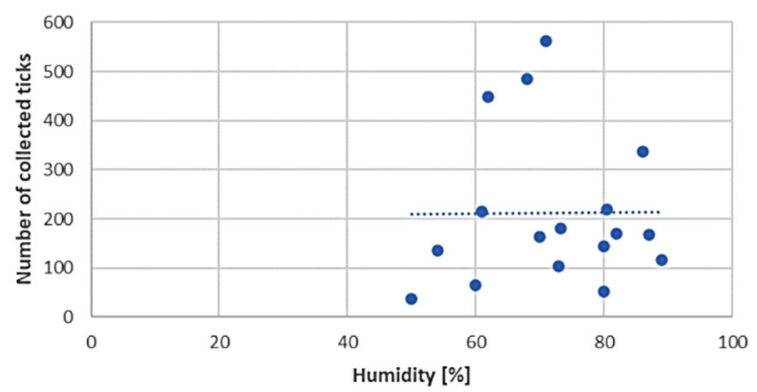

Plot E

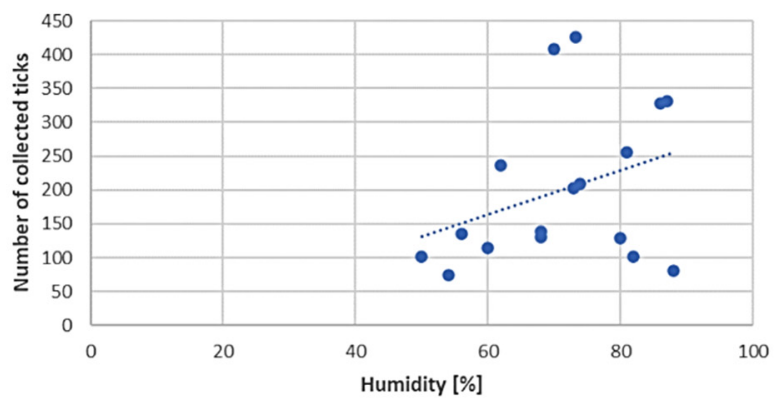

Plot B

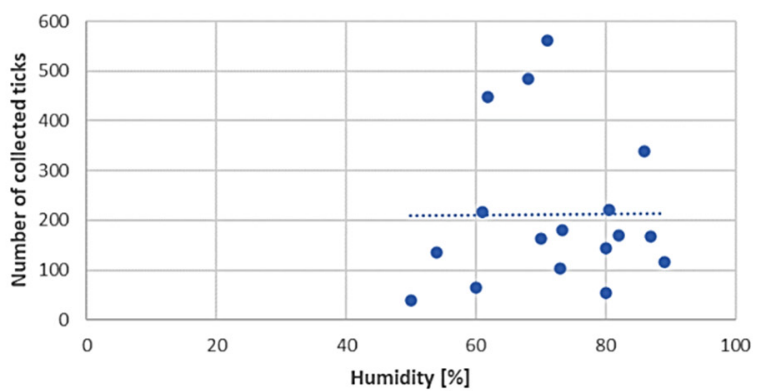

Plot D

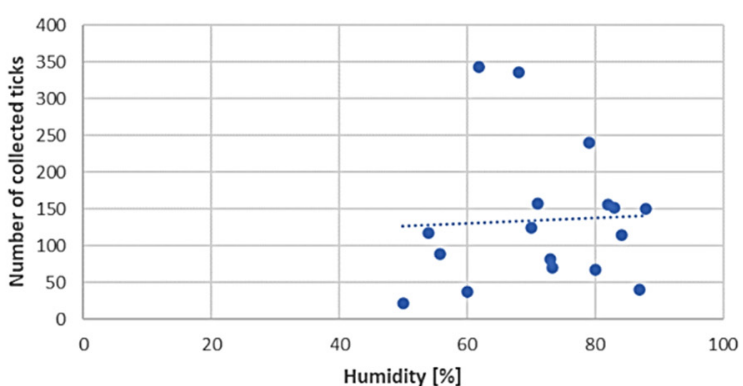

Plot F

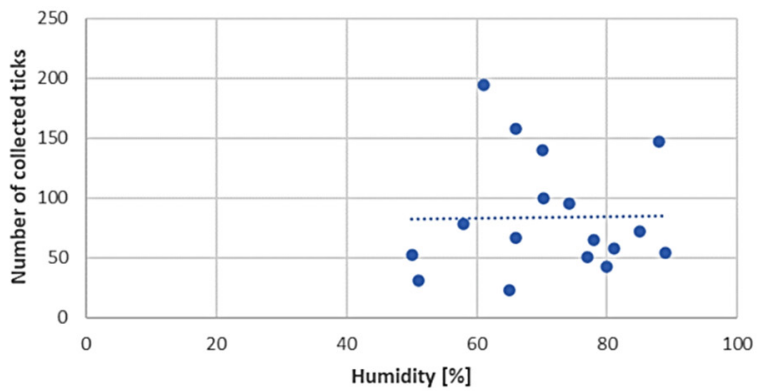

Plot G

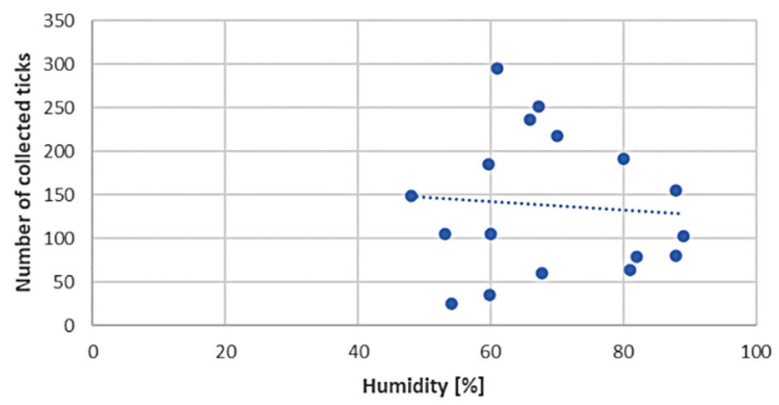

Figure 11. Relationships between relative air humidity and the number of active Dermacentor reticulatus adults in the research plots.

\section{Discussion}

Dermacentor reticulatus ticks exhibit a wide range of tolerance to prevailing weather conditions [14]. They are active in a wide range of temperatures, also in winter months at positive air temperatures and absence of snow cover [32]. During the present study, adult $D$. reticulatus specimens were collected in a temperature range of $5.0-27.0^{\circ} \mathrm{C}$ (Table 2 , 
Figures 3-10). In other studies conducted in eastern Poland, specimens of this species were collected at a temperature of $34.6^{\circ} \mathrm{C}$ [33]. The results indicate a negative correlation between the number of collected ticks and air temperature. This relationship is probably associated with the fact that the greatest numbers of ticks were collected at a lower ambient temperature in autumn in a majority of the plots. The significant effect of temperature on the activity of $D$. reticulatus was also confirmed in other multi-season studies $[33,34]$. As in the case of other ixodid ticks [35-37], the air temperature exerts an impact on the questing activity of $D$. reticulatus $[13,30]$, stimulates the rhythms of seasonal tick activity, and induces diapause [38]. This phenomenon is clearly evident in summer in the temperate climate zone when adults are inactive or only a few ticks are active [31,34]. The increase in air temperature reduces the locomotor activity of D. reticulatus [29], which is most probably associated with protection from undesirable water loss. Ticks exposed to substantial water loss die $[39,40]$. In turn, an increase in the relative humidity in the habitat stimulates locomotor activity in ticks [29].

D. reticulatus ticks were collected in every research plot in the present study. The statistical analysis did not show any significant differences in the vegetation structure in the research plots; however, previous studies have revealed these ticks are characterized by high plasticity in relation to the habitats occupied [14,41]. As shown by previous studies conducted in eastern Poland and other countries of this part of the continent, the most abundant $D$. reticulatus populations inhabit lowland areas, which are often covered by unused meadows and fallow land [21,42-45], in contrast to Western European countries, where this species is collected mostly in forest/semi-forest ecosystems or along the seashore [46-48]. In the present study, the predominant plant communities in the analyzed area were fresh semi-natural meadow communities from the class Molinio-Arrhenatheretea, which should be regarded as one of the preferred habitats of $D$. reticulatus populations in eastern Poland due to their high abundance.

The $D$. reticulatus populations in the Wieprz River valley as per the current results can be regarded as highly abundant (Figures 3-11). Equally large populations of $D$. reticulatus have been reported by Široký et al. [49] in the Czech Republic (investiagators collected up to 222 specimens per hour). An increase in the D. reticulatus population size and occurrence range in recent years has been observed in other European countries as well, e.g., in Germany and Slovakia $[50,51]$. Substantially smaller populations of D. reticulatus have been reported from other parts of Poland, e.g., Mierzejewska et al. [18] collected on average 7.4 specimens $/ 100 \mathrm{~m}^{2}$ in the central part of the country (Mazowieckie Province), 6.20 specimens $/ 100 \mathrm{~m}^{2}$ in western Poland, and 3.04 specimens $/ 100 \mathrm{~m}^{2}$ in the north of the country. In the present study, we observed co-occurrence of D. reticulatus and I. ricinus in the same habitats. This phenomenon has a positive effect on both species, especially in terms of their host-questing activity, feeding period, embryonic development and survival of immature stages [52].

The analyzed $D$. reticulatus populations differed in the number of active specimens in spring and summer (Figures 3-11). The autumn peak predominated in plots located in the lower (plots A, B) and upper (plots F, G) course of the river. In the middle course of the river (plots $C$ and $E$ ), greater numbers of active ticks were collected in spring (Figures 3-9, Table 2). A multiyear study of $D$. reticulatus activity in eastern Poland demonstrated even threefold higher numbers of active ticks in autumn [33,34]. This changed in the 2018/2019 season, i.e., the dominance of the spring peak was observed for the first time in some of the research plots located in the region [21]. It was previously believed that, depending on their geographical range in Europe, D. reticulatus exhibit higher activity either in spring (e.g., Russia, France, North-Eastern Poland) or in autumn (Eastern Poland, Central Europe). The seasonality of the activity peaks was ascribed to the adaptation of local populations to thermal conditions and host availability $[44,53]$.

Therefore, especially interesting was the number of active $D$. reticulatus adults observed in plot $\mathrm{G}$ (on average 179.8 active specimens in autumn 2018, 148.8 specimens in spring 2019, and 64.5 specimens in autumn 2019) and in plot E (on average 163.8 specimens 
per collection in autumn 2018, 255.0 specimens in spring 2019, and 136.0 specimens in autumn 2019) (Table 2). The reversal of the patterns of the D. reticulatus seasonal activity in eastern Poland has not been fully elucidated. The phenomenon observed may be a result of the drastic decline in the population of the wild boar Sus scrofa (regarded as one of the preferred hosts of $D$. reticulatus adults). As estimated by Hunting Clubs, the wild boar population in Lubelskie Province decreased from 7156 to 275 individuals over the last three years [54]. Due to the epidemic of African swine fever spreading in the study area since 2017, wild boars have been subjected to culling in order to stop the spread of the disease. Concurrently, we want to clearly emphasize that the exact determinants of this phenomenon have not been elucidated to date and require further research.

Ecological corridors facilitate undisturbed migration of animals, including small rodents [55], which are the main hosts of juvenile D. reticulatus stages, and mediumand large-sized mammals [2,56], i.e., hosts of mature stages. Our studies show that Apodemus agrarius, Microtus arvalis, and Myodes glareolus are the most abundant rodent species in the Wieprz River valley [57]. All these species are commonly regarded as the preferred hosts for $D$. reticulatus larvae and nymphs $[47,58]$. Furthermore, there are relatively numerous populations of large ungulates Capreolus capreolus, Cervus elaphus, and Alces alces in eastern Poland $[54,59]$. Previous studies indicate that they are frequently infested by adult $D$. reticulatus [14]. The daily distance covered by the moose and roe deer has been estimated at ca. $2 \mathrm{~km}$ and over $4 \mathrm{~km}$, respectively [60]. The mobility of these animals allows ticks to cover certain distances. Moreover, thanks to their biology and ecology, these animals can easily move outside the ecological corridors, thus contributing to the transport of ticks between habitats. The role of birds in the transportation of ticks in these areas is not fully understood. Some studies conducted in northern Poland indicate the possibility of transportation of $D$. reticulatus larvae on birds [61]. Similarly, as reported from other European countries (Norway), blackbirds or thrushes can transport tick larvae (from the genera Ixodes, Hyalomma, Dermacentor) on their bodies [62].

Due to the high abundance of local populations of $D$. reticulatus in the ecological corridor of the Wieprz River and the dominance of meadow vegetation (preferred by this species) along the river valley, migrating animals can be easily attacked by these ticks. In turn, thanks to the long duration of feeding of adult stages on animals [63] and the possibility of overwintering in animal fur [64], ticks can be transported over long distances.

\section{Conclusions}

Adult Dermacentor reticulatus ticks occur along the entire ecological corridor in the Wieprz River valley. The local populations of D. reticulatus are characterized by predominance of either spring or autumn activity peaks. Given the high abundance of the studied D. reticulatus populations, the habitats of the ecological corridor of the Wieprz River can be regarded as preferred habitats of this tick species.

Author Contributions: Conceptualization, Z.Z.; methodology, Z.Z.; field research Z.Z.; A.W.; J.K.; writing—original draft preparation, Z.Z.; A.S.; W.M.; A.W.; J.K.; writing—review and editing, Z.Z.; A.S.; W.M.; A.W.; J.K. All authors have read and agreed to the published version of the manuscript.

Funding: This research received no external funding.

Institutional Review Board Statement: Ethical review and approval were waived for this study, due to fact that this study reported research on invertebrates not covered by species protection. Due to Polish law, this type of research does not require the consent of the relevant authorities.

Data Availability Statement: The data that support the findings of this study are available from the corresponding authors, upon reasonable request.

Conflicts of Interest: The authors declare no conflict of interest. 


\section{Appendix A}
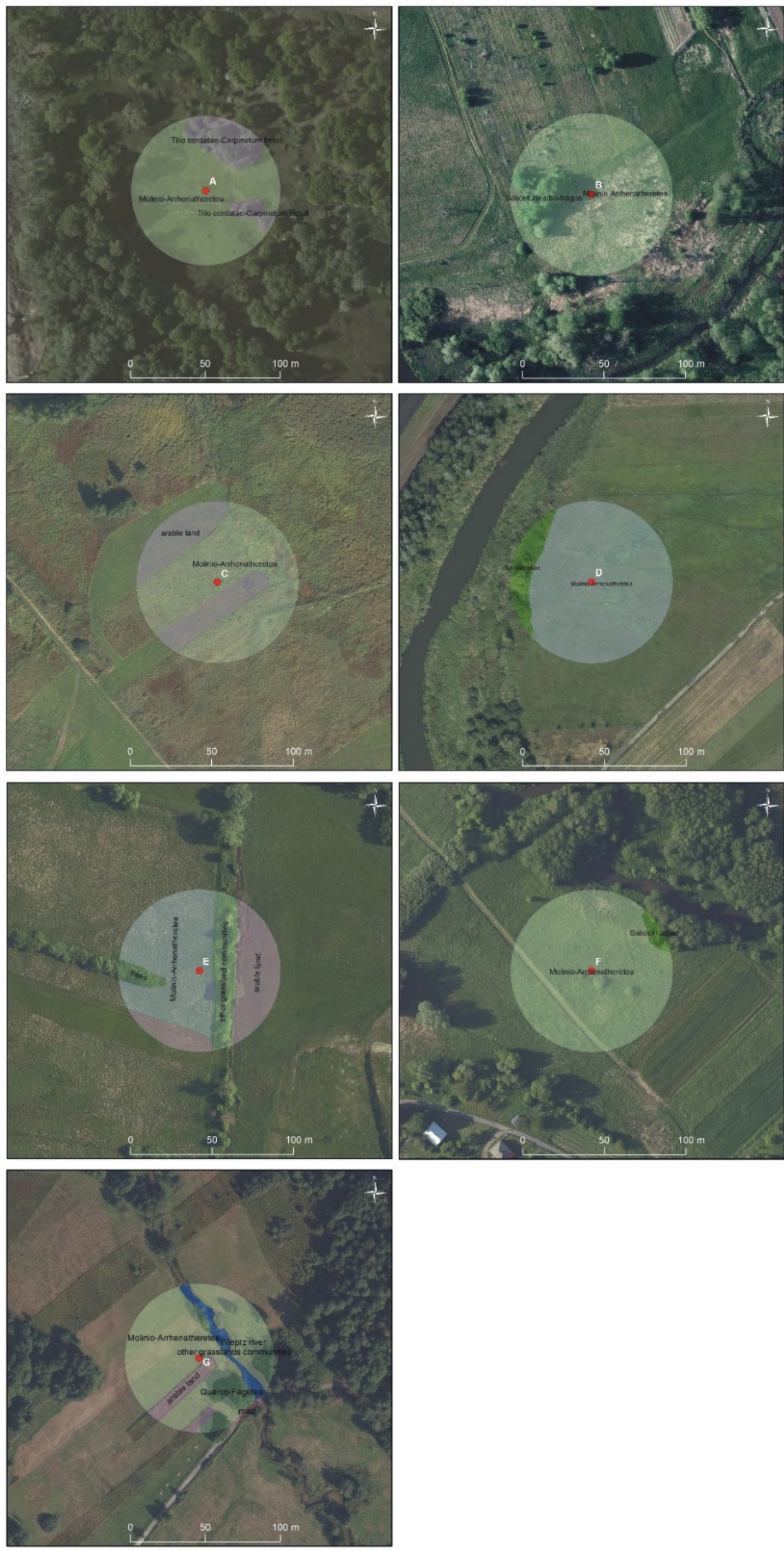

Figure A1. Structure of plant communities in research plots. 


\section{References}

1. Rodriguez-Iturbe, I.; Muneepeerakul, R.; Bertuzzo, E.; Levin, S.A.; Rinaldo, A. River networks as ecological corridors: A complex systems perspective for integrating hydrologic, geomorphologic, and ecologic dynamics. Water Resour. Res. 2009, 45. [CrossRef]

2. Romanowski, J. Vistula river valley as the ecological corridor for mammals. Pol. J. Ecol. 2007, 55, 805.

3. Peng, J.; Zhao, H.; Liu, Y. Urban ecological corridors construction: A review. Acta Ecol. Sin. 2017, 37, 23-30. [CrossRef]

4. Available online: https://inspire.ec.europa.eu/codelist/SupplementaryRegulationValue/1_4_1_EcologicalCorridor (accessed on 1 November 2020).

5. Bruinderink, G.G.; Van Der Sluis, T.; Lammertsma, D.; Opdam, P.; Pouwels, R. Designing a coherent ecological network for large mammals in northwestern Europe. Conserv. Biol. 2003, 17, 549-557. [CrossRef]

6. Wojciechowski, K. Wdrażanie idei korytarzy ekologicznych. In Problemy Ekologii Krajobrazu; Ciszewska, A., Ed.; Wydawnictwo SGGW: Warszawa, Polska, 2004; Volume 14, pp. 221-228. ISBN 83-7244-586-9.

7. Jędrzejewski, W.; Nowak, S.; Stachura, K.; Skierczyński, M.; Mysłajek, R.W.; Niedziałkowski, K.; Jędrzejewska, B.; Wójcik, J.M.; Zalewska, H.; Pilot, M.; et al. Projekt Korytarzy Ekologicznych Łaczacych Europejska Sieć Natura 2000 w Polsce; Zakład Badania Ssaków PAN: Białowieża, Poland, 2011; Available online: https://korytarze.pl/mapa/mapa-korytarzy-ekologicznych-w-polsce (accessed on 1 November 2020).

8. Scott, J.D.; Foley, J.E.; Anderson, J.F.; Clark, K.L.; Durden, L.A. Detection of Lyme disease bacterium, Borrelia burgdorferi sensu lato, in blacklegged ticks collected in the Grand River Valley, Ontario, Canada. Int. J. Med. Sci. 2017, 14, 150. [CrossRef] [PubMed]

9. Weisbrod, A.R.; Johnson, R.C. Lyme disease and migrating birds in the Saint Croix River Valley. Appl. Environ. Microbiol. 1989, 55, 1921-1924. [CrossRef] [PubMed]

10. Pistone, D.; Pajoro, M.; Fabbi, M.; Vicari, N.; Marone, P.; Genchi, C.; Bandi, C. Lyme borreliosis, Po River Valley, Italy. Emerg. Infect. Dis. 2010, 16, 1289. [CrossRef]

11. Wilkinson, P.R. The distribution of Dermacentor ticks in Canada in relation to bioclimatic zones. Can. J. Zool. 1967, 45, 517-537. [CrossRef]

12. Zygner, W.; Górski, P.; Wedrychowicz, H. New localities of Dermacentor reticulatus tick (vector of Babesia canis canis) in central and eastern Poland. Pol. J. Vet. Sci. 2009, 12, 549.

13. Kohn, M.; Krücken, J.; McKay-Demeler, J.; Pachnicke, S.; Krieger, K.; von Samson-Himmelstjerna, G. Dermacentor reticulatus in Berlin/Brandenburg (Germany): Activity patterns and associated pathogens. Ticks Tick Borne Dis. 2019, 10, 191-206. [CrossRef]

14. Földvári, G.; Široký, P.; Szekeres, S.; Majoros, G.; Sprong, H. Dermacentor reticulatus: A vector on the rise. Parasit. Vectors 2016, 9, 314. [CrossRef] [PubMed]

15. Oteo, J.A.; Portillo, A. Tick-borne rickettsioses in Europe. Ticks Tick Borne Dis. 2012, 3, 271-278. [CrossRef] [PubMed]

16. Zając, V.; Wójcik-Fatla, A.; Sawczyn, A.; Cisak, E.; Sroka, J.; Kloc, A.; Zając, Z.; Buczek, A.; Dutkiewicz, J.; Bartosik, K. Prevalence of infections and co-infections with 6 pathogens in Dermacentor reticulatus ticks collected in eastern Poland. Ann. Agric. Environ. Med. 2017, 24, 26-32. [CrossRef] [PubMed]

17. Ličková, M.; Havlíková, S.F.; Sláviková, M.; Slovák, M.; Drexler, J.F.; Klempa, B. Dermacentor reticulatus is a vector of tick-borne encephalitis virus. Ticks Tick Borne Dis. 2020, 11, 101414. [CrossRef] [PubMed]

18. Mierzejewska, E.J.; Estrada-Peña, A.; Alsarraf, M.; Kowalec, M.; Bajer, A. Mapping of Dermacentor reticulatus expansion in Poland in 2012-2014. Ticks Tick Borne Dis. 2016, 7, 94-106. [CrossRef] [PubMed]

19. Kiewra, D.; Szymanowski, M.; Czułowska, A.; Kolanek, A. The local-scale expansion of Dermacentor reticulatus ticks in Lower Silesia, SW Poland. Ticks Tick Borne Dis. 2020, 101599. [CrossRef]

20. Kubiak, K.; Sielawa, H.; Dziekońska-Rynko, J.; Kubiak, D.; Rydzewska, M.; Dzika, E. Dermacentor reticulatus ticks (Acari: Ixodidae) distribution in north-eastern Poland: An endemic area of tick-borne diseases. Exp. App. Acarol. 2018, 75, 289-298. [CrossRef]

21. Zając, Z.; Woźniak, A.; Kulisz, J. Density of Dermacentor reticulatus Ticks in Eastern Poland. Int. J. Environ. Res. 2020, 17, 2814. [CrossRef]

22. Piekarska, K. Fizjografia dolin rzecznych Bugu, Wieprza, Tyśmienicy. In Ptaki Wybranych Dolin Rzecznych Lubelszczyzny; Piotrowska, M., Piekarska, K., Jobda, M., Rzepkowski, R., Jujka-Radziewicz, M., Stasiak, K., Krogulec, J., Ebertowska, B., Choroś, J., Eds.; OTOP Press: Marki, Polska, 2016; pp. 11-20. ISBN 978-83-89830-26-5.

23. Gallé, L.; Margóczi, K.; Kovács, É.; Györffy, G.; Körmöczi, L.; Németh, L. River valleys: Are they ecological corridors. Tiscia 1995, $29,53-58$.

24. Kondracki, J. Geografia Regionalna Polski; Wydawnictwo Naukowe PWN: Warszawa, Polska, 2000; ISBN 9788301160227.

25. Matuszkiewicz, W. Przewodnik do Oznaczania Zbiorowisk Roślinnych Polski; Wydawnictwo Naukowe PWN: Warszawa, Poland, 2001; Volume 3.

26. Geoportal. Available online: https://mapy.geoportal.gov.pl/imap/Imgp_2.html (accessed on 1 November 2020).

27. Lu, D.; Weng, Q. A survey of image classification methods and techniques for improving classification performance. Int. J. Remote Sens. 2007, 28, 823-870. [CrossRef]

28. Lechowski, Ł. Analiza zmian pokrycia terenu wokół autostrad za pomoca metod GIS. Acta Univ. Lodz. Folia Geogr. SocioOeconomica 2013, 14, 59-76.

29. Buczek, A.; Zając, Z.; Woźniak, A.; Bartosik, K. Locomotor activity of adult Dermacentor reticulatus ticks (Ixodida: Ixodidae) in natural conditions. Ann. Agric. Environ. Med. 2017, 24, 271-275. [CrossRef] [PubMed] 
30. Bartosik, K.; Wiśniowski, Ł.; Buczek, A. Questing behavior of Dermacentor reticulatus adults (Acari: Amblyommidae) during diurnal activity periods in eastern Poland. J. Med. Entomol. 2012, 49, 859-864. [CrossRef] [PubMed]

31. Nowak-Chmura, M. Fauna kleszczy (Ixodida) Europy Środkowej; Wydawnictwo Naukowe Uniwersytetu Pedagogicznego: Kraków, Polska, 2013; ISBN 978-83-7271-829-7.

32. Kiewra, D.; Czułowska, A.; Lonc, E. Winter activity of Dermacentor reticulatus (Fabricius, 1794) in the newly emerging population of Lower Silesia, south-west Poland. Ticks Tick Borne Dis. 2016, 7, 1124-1127. [CrossRef] [PubMed]

33. Zajac, Z.; Bartosik, K.; Buczek, A. Factors influencing the distribution and activity of Dermacentor reticulatus (F.) ticks in an anthropopressure-unaffected area in central-eastern Poland. Ann. Agric. Environ. Med. 2016, 23, 270-275. [CrossRef] [PubMed]

34. Buczek, A.; Bartosik, K.; Wisniowski, L.; Tomasiewicz, K. Changes in population abundance of adult Dermacentor reticulatus (Acari: Amblyommidae) in long-term investigations in eastern Poland. Ann. Agric. Environ. Med. 2013, 20, 269-272. [PubMed]

35. Vail, S.G.; Smith, G. Air temperature and relative humidity effects on behavioral activity of blacklegged tick (Acari: Ixodidae) nymphs in New Jersey. J. Med. Entomol. 1998, 35, 1025-1028. [CrossRef]

36. Li, S.; Gilbert, L.; Vanwambeke, S.O.; Yu, J.; Purse, B.V.; Harrison, P.A. Lyme disease risks in Europe under multiple uncertain drivers of change. Environ. Health Perspect. 2019, 127, 067010. [CrossRef]

37. Süss, J.; Klaus, C.; Gerstengarbe, F.W.; Werner, P.C. What makes ticks tick? Climate change, ticks, and tick-borne diseases. J. Travel. Med. 2008, 15, 39-45. [CrossRef]

38. Belozerov, V.N. Diapause and biological rhythms in ticks. In Physiology of Ticks, 1st ed.; Obenchain, F.D., Galun, R., Eds.; Pergamon Press: Oxford, UK, 1982; pp. 469-500. ISBN 978-0-08-024937-7.

39. Knülle, W.; Rudolph, D. Humidity relationships and water balance of ticks. In Physiology of Ticks, 1st ed.; Obenchain, F.D., Galun, R., Eds.; Pergamon Press: Oxford, UK, 1982; pp. 43-70. ISBN 978-0-08-024937-7.

40. Hair, J.A.; Sauer, J.R.; Durham, K.A. Water balance and humidity preference in three species of ticks. J. Med. Entomol. 1975, 12, 37-47. [CrossRef]

41. Rubel, F.; Brugger, K.; Pfeffer, M.; Chitimia-Dobler, L.; Didyk, Y.M.; Leverenz, S.; Kahl, O. Geographical distribution of Dermacentor marginatus and Dermacentor reticulatus in Europe. Ticks Tick Borne Dis. 2016, 7, 224-233. [CrossRef] [PubMed]

42. Zając, Z.; Woźniak, A.; Kulisz, J. Infestation of dairy cows by ticks Dermacentor reticulatus (Fabricius, 1794) and Ixodes ricinus (Linnaeus, 1758) in eastern Poland. Ann. Parasitol. 2020, 66, 87-96. [CrossRef] [PubMed]

43. Biaduń, W. New habitats of Dermacentor reticulatus (Fabricius, 1794) in the Lublin region. Ann. Parasitol. $2011,5,83$.

44. Razumova, I.V. The activity of Dermacentor reticulatus Fabr.(Ixodidae) ticks in nature. Med. Parzitol. (Mosk) 1998, 4, 8-14.

45. Bajer, A.; Rodo, A.; Alsarraf, M.; Dwużnik, D.; Behnke, J.M.; Mierzejewska, E.J. Abundance of the tick Dermacentor reticulatus in an ecosystem of abandoned meadows: Experimental intervention and the critical importance of mowing. Vet. Parasitol. 2017, 246, 70-75. [CrossRef]

46. Medlock, J.M.; Hansford, K.M.; Vaux, A.G.C.; Cull, B.; Abdullah, S.; Pietzsch, M.E.; Wall, R.; Johnson, N.; Phipps, L.P. Distribution of the tick Dermacentor reticulatus in the United Kingdom. Med. Vet. Entomol. 2017, 31, 281-288. [CrossRef]

47. Pfäffle, M.; Littwin, N.; Petney, T. Host preferences of immature Dermacentor reticulatus (Acari: Ixodidae) in a forest habitat in Germany. Ticks Tick Borne Dis. 2015, 6, 508-515. [CrossRef]

48. Olivieri, E.; Gazzonis, A.L.; Zanzani, S.A.; Veronesi, F.; Manfredi, M.T. Seasonal dynamics of adult Dermacentor reticulatus in a peri-urban park in southern Europe. Ticks Tick Borne Dis. 2017, 8, 772-779. [CrossRef]

49. Šriroký, P.; Kubelová, M.; Bednář, M.; Modrý, D.; Hubálek, Z.; Tkadlec, E. The distribution and spreading pattern of Dermacentor reticulatus over its threshold area in the Czech Republic-how much is range of this vector expanding? Vet. Parasitol. 2011, 183, 130-135. [CrossRef]

50. Drehmann, M.; Springer, A.; Lindau, A.; Fachet, K.; Mai, S.; Thoma, D.; Schneider, C.R.; Chitimia-Dobler, L.; Bröker, M.; Dobler G.; et al. The Spatial Distribution of Dermacentor Ticks (Ixodidae) in Germany-Evidence of a Continuing Spread of Dermacentor reticulatus. Front. Vet. Sci. 2020, 7, 578220. [CrossRef]

51. Bullová, E.; Lukáň, M.; Stanko, M.; Pet'ko, B. Spatial distribution of Dermacentor reticulatus tick in Slovakia in the beginning of the 21st century. Vet. Parasitol. 2009, 165, 357-360. [CrossRef] [PubMed]

52. Bartosik, K. Mutual Interactions between Prostriata and Metastriata Ticks (Acari: Ixodida: Ixodidae) in Parasitic and Nonparasitic Phase of the Life Cycle. Ph.D. Thesis, Medical University of Lublin, Lublin, Poland, 2006. (In Polish).

53. Martinod, S.; Gilot, B. Epidemiology of canine babesiosis in relation to the activity of Dermacentor reticulatus in southern Jura (France). Exp. Appl. Acarol. 1991, 11, 215-222. [CrossRef] [PubMed]

54. The Size of the Game Animals Population in Poland. Available online: http://www.czempin.pzlow.pl/palio/html.run? _Instance=pzl_www\&_PageID=21\&_CAT=CZEMPIN.MATERIALY (accessed on 1 November 2020).

55. Szacki, J. Ecological corridor as a factor determining the structure and organization of a bank vole population. Acta Theriol. 1987, 32, 31-44. [CrossRef]

56. Obiegala, A.; Pfeffer, M.; Pfister, K.; Karnath, C.; Silaghi, C. Molecular examinations of Babesia microti in rodents and rodentattached ticks from urban and sylvatic habitats in Germany. Ticks Tick Borne Dis. 2015, 6, 445-449. [CrossRef]

57. Zając, Z.; Kulisz, J.; Woźniak, A. Flea Communities on Small Rodents in Eastern Poland. Insects 2020, 11, 894. [CrossRef]

58. Dwużnik, D.; Mierzejewska, E.J.; Drabik, P.; Kloch, A.; Alsarraf, M.; Behnke, J.M.; Bajer, A. The role of juvenile Dermacentor reticulatus ticks as vectors of microorganisms and the problem of 'meal contamination'. Exp. Appl. Acarol. 2019, 78, 181-202. [CrossRef] 
59. Cios, H. Risk Assessment for Ixodes Ricinus Tick Attacks in Various Climatic Regions of the Lublin Region. Ph.D. Thesis, Medical University of Lublin, Lublin, Poland, 2014. (In Polish).

60. Pfeffer, S.E.; Spitzer, R.; Allen, A.M.; Hofmeester, T.R.; Ericsson, G.; Widemo, F.; Cromsigt, J.P. Pictures or pellets? Comparing camera trapping and dung counts as methods for estimating population densities of ungulates. Remote Sens. Ecol. Conserv. 2018, 4, 173-183. [CrossRef]

61. Ciebiera, O.; Jerzak, L.; Nowak-Chmura, M.; Bocheński, M. Ticks (Acari: Ixodida) on birds (Aves) migrating through the Polish Baltic coast. Exp. App. Acarol. 2019, 77, 241-251. [CrossRef]

62. Hasle, G.; Bjune, G.; Edvardsen, E.; Jakobsen, C.; Linnehol, B.; Røer, J.E.; Mehl, R.; Røed, K.H.; Pedersen, J.; Leinaas, H.P. Transport of ticks by migratory passerine birds to Norway. J. Parasitol. 2009, 95, 1342-1351. [CrossRef]

63. Buczek, A.; Bartosik, K.; Zajac, Z.; Stanko, M. Host-feeding behaviour of Dermacentor reticulatus and Dermacentor marginatus in mono-specific and inter-specific infestations. Parasit. Vectors 2015, 8, 1-5. [CrossRef]

64. Izdebska, J.N. The occurrence of Dermacentor reticulatus (Fabricius, 1794)(Acari, Ixodidae) on the bison (Bison bonasus) from the Białowieża Primaeval Forest. Przegl. Zool. 1998, 42, 219-221. 